\title{
A SZUBURBANIZÁCIÓ JELENSÉGÉNEK FÖBB ELMÉLETI MEGKÖZELÍTÉSEI A VÁROSSZOCIOLÓGIAI ÉS MÁS ROKON TUDOMÁNYTERÜLETEK IRODALMÁBAN
}

\author{
(Principal Theoretical Approaches of the Phenomenon of \\ Suburbanisation in the Literature of Urban Sociology \\ and Other Related Sciences)
}

\section{KOCSIS JÁNOS BALÁZS}

A szuburbanizáció jelenségével a városszociológia mellett leginkább még az építészet és a földrajz valamely területéröl jövök foglalkoznak. Az általuk használt fogalmak jelentése, a hipotézisek jelentős mértékben eltérnek, a vizsgált téma másmás oldalára világítanak rá. Az alábbiakban leginkább a (város)szociológiai megközelítésböl mutatjuk be a föbb irányzatokat.

A szuburbanizáció mint folyamat fogalmát leginkább az amerikai szociológiai irodalomhoz (Fishman 1987; Frieden-Sagalyn 1997; Garreau 1991; Jackson 1985) hasonlóan, szük értelemben használjuk, azaz a középosztályi családoknak a város belsö részeiböl annak peremére való nagy arányú költözését értve alatta. A szuburbanizáció jelenségével foglalkozó irodalom nagy része Amerikában keletkezett, az ottani, az európaitól jelentősen különbözỏ folyamatok leírásával kapcsolatban. Részint a fogalmi egyértelmüség érdekében, részint mivel a mai magyarországi városfejlödési folyamatok egy jelentős csoportja jól megfeleltethetö e keretben is, a nem szúken e körbe tartozó folyamatokra más fogalmak használatát tartjuk szükségesnek.

Az elméleti megközelítéseket Szelényi (1996) alapján két föbb csoportra tagoljuk ${ }^{1}$ $(1 ., 2$. ábra $)$. A két modell közötti alapvető elméleti eltérés abban mutatkozik, hogy mit tekintenek független és közbejövö változónak az urbanizáció, mint függő változó vizsgálatában.

\section{Azökológiai vagy evolúciós megközelítés}

\section{Az elmélet}

Az ökológiai megközelítés az indusztrializációt tekinti független változónak. A modell végkövetkeztetése szerint egyazon városfejlődési modell ${ }^{2}$ alapján fejlődik minden város. $\mathrm{Az}$ azonos stádiumban lévő városok jellemzőin a társadalmi-gazdasági szerkezet módosít; a városok minden társadalomban az indusztrializácí́ adott fokához tartozó városfejlödési állapotban vannak (Savage-Warde 1993). A fejlődési stádiumok időben mindenhol ugyanabban a sorrendben követik egymást, az 
Kocsis János Balázs : A szuburbanizáció jelenségének föbb elméleti megközelítései a városszociológiai és más rokon tudományterületek irodalmában. Tér és Társadalom 14. évf. 2000/2-3. 311-321. p.

egyes fokozatok mindenhol előbb-utóbb megjelennek. A fejlödés egyetemleges, a helyi sajátosságok csak módosítanak a jellemzőkön, mint Enyedi György írja: „a szocialista országokban kialakult regionális szerkezet és urbanizációs típus nem önálló modell. Az európai szocialista országok ugyanazokat az urbanizációs és regionális fejlődési szakaszokat produkálták, amelyeken a nyugati országok már korábban átjutottak. Nem pontos másolat, jelentősek a kelet-közép-európai sajátosságok... A magyar regionális fejlödés tehát az általános európai fejlödés egyik változatának tekintjük" (Enyedi 1996, 12, kiemelés a szerzőtöl). Ezen elmélet szerint a magyar városok fejlödése jelentős, de nem meghatározó különbségek mellett az általános modellt követik megkésve, amely késedelem oka az indusztrializációban való megkésettségben keresendô. Ha a magyar indusztrializáció olyan fokra ér, mint a mai nyugati (eltérỏ nézỏpontból például posztfordista [Enyedi 1996], posztindusztriális, információs) gazdaság, akkor az (akkori) magyarországi városszerkezet is alapvetỏen egyezni fog a megfelelő nyugati formával.

\section{1. ÁBRA}

Az urbanizációs folyamat ökológiai magyarázata

(Ecological Interpretation of the Urbanisation Process)

Független változó

Közbejövő változó(k)

Függő változó

társadalmi-gazdasági szerkezet

indusztrializáció

urbanizáció

Forrás: Szelényi 1996, 289.

A modell ( $I$. ábra) egyik fỏ nehézsége a gazdaság alapvetỏ szerepének hangsúlyozásából fakad. Az ipar szerepe a modern kapitalizmusban a dezindusztrializációval csökken, azaz az iparnak a városok fejlödésében betöltött szerepe is csökken, az e modellek alapjául szolgáló föltevést módosítani kell ${ }^{3}$. Mások a modell alapjául szolgáló megfigyelés, azaz a városok növekedésének megállása illetve negatív irányba fordulása általánosításának veszélyeire hívják fel a figyelmet (Savage-Warde 1993), azzal érvelve, hogy a városok népesedésének csökkenése lehet egy térben és idöben behatárolt folyamat, amelyböl általános következtetéseket óvatosan szabad csak levonni.

\section{Azökológiai megközelítésekhez tartozó néhány modell}

Az alábbiakban két, egymáshoz meglehetősen hasonlitó modellt vázolunk fel, amely sok helyütt megtalálható a szakirodalomban. A két modell hasonlóságát az okozza, hogy mindkettő nagyrészt amerikai, kisebb részben nagyobb nyugateurópai városokban tapasztalható folyamatok elemzésével és általánosításával és időbeni „spekulatív extrapolálásával” készült. Az ökológiai alapfeltevés értelmében 
Kocsis János Balázs : A szuburbanizáció jelenségének föbb elméleti megközelítései a városszociológiai

és más rokon tudományterületek irodalmában. Tér és Társadalom 14. évf. 2000/2-3. 311-321. p.

TÉT XIV. évf. 2000 -2-3

A szuburbanizáció jelenségének... 313

a városok mind besorolhatók a modell valamelyik urbanizációs fejlettségi fokába, $\mathrm{s}$ ez a fejlettségi fok az adott társadalom indusztrializációs fejlettségi fokának megfelelö lesz.

\section{A) Peter Hall hatfázisos evolúciós modellje}

Peter Hall evolúciós modelljébe mind az indusztrializáció, mind a dezindusztrializáció hatásait bevonja. Amerikai városfejlődési tapasztalatok alapján a következö folyamatok ásták alá a korábbi kapitalista éra nagyvárosait:

- szuburbanizáció, a városi növekedés inkább a szuburbiában, mint a központi területeken jelentkezik,

- dezurbanizáció, a városi népesség csökken a falusi és nem városi népességhez képest,

- a legnagyobb városok összehúzódása,

- új régiók felemelkedése és a régiek hanyatlása.

A városfejlődés általa vázolt hat fokozata két csoportra oszlik. Az elsö három az indusztrializáció, azaz a városok növekedése, a másik a dezindusztrializáció, azaz a városok hanyatlása kapcsán lép fel.

1) A kezdeti indusztrializáció kapcsán az emberek vidékről a városba áramlanak, a városi népesség nö, azonban a régió össznépessége csökken, mivel összességében több ember hagyja el a régiót.

2) Az indusztrializáció folytatódásával növekszik a városi népesség aránya a régióban.

3) „Relativ centralizáció”, azaz a város kinyúlik eredeti határain túlra, és szuburbiákat hoz létre. Mindezek ellenére a városi népesség aránya a régióban növekszik ${ }^{6}$. Hall állítása szerint a városi növekedés e fázisokon már túllépett, és a városok hanyatlása kapcsán a következỏ szakaszok léptek fel:

4) A szuburbiák gyorsabban növekednek, mint a városmag, az emberek a város külsőbb részeibe költöznek, ez a „relatív decentralizáció” szakasza.

5) 1900-től kezdődően (de inkább manapság) „abszolút decentralizáció” lépett fel a nagyobb európai városokban, az emberek kiköltöznek a belvárosból, ahogy az egyre inkább irodai és kereskedelmi funkciókat vesz fel.

6) Az egész város hanyatlani kezd, amint az emberek falusi környezetbe költöznek a dezindusztrializáció előrehaladásával.

Hall modellje általános érvényü kíván lenni amerikai eredete ellenére. Az általa várt változások következtek be némely európai országban, azonban jelentős térségekben, Franciaországban, Olaszországban és a Benelux államokban a várt hanyatlás elmaradt (Savage-Warde 1993). A városok hanyatlása helyett a városok további növekedése figyelhető meg a kapitalista társadalmakban.

\section{B) A négyfázisos modell}

Ennek a gyakran megtalálható modellnek a leírását Tosits (1998) és $L$. van den Berg (1982) alapján foglaljuk össze röviden. 
Kocsis János Balázs : A szuburbanizáció jelenségének föbb elméleti megközelítései a városszociológiai és más rokon tudományterületek irodalmában. Tér és Társadalom 14. évf. 2000/2-3. 311-321. p.

314 Kocsis János Balázs

TÉT XIV. évf. 2000 2-3

A modell nagyon hasonlít az előzőhöz, azonban időben és extrapolációban túlmegy rajta, megpróbálva belevonni a belvárosi dzsentrifikáció vagy manhattanizáció sok nyugati városban megfigyelt jelenségét.

\section{1) Urbanizáció}

A mezőgazdasági területek felesleges népességét a város fel tudja már szívni, az addigi fölös népességet lecsapoló eljárások (például kivándorlás, járványok) megléte mellett. $\mathrm{E}$ fölös népesség részben a természetes szaporulatból, részben a mezögazdasági eljárások fejlődése kapcsán alakult ki. A beáramló népesség részben a hosszú munkaidö, részben a tömegközlekedés hiánya miatt koncentráltan, a munkahelyhez közel telepszik le, a régi városközpontokat körülvevő vagy új, az ipar számára valamilyen okból vonzó térségekben. Ez a folyamat az Ipari Forradalom alatt indult meg elöször Angliában, majd több-kevesebb késéssel Európa más tájain is, néhol csak a második világháború után.

Az urbanizáció által megnövekedett városok térbeli elhelyezkedése az adott ország illetve régió történelmi, politikai és gazdasági helyzetétől függ, s alakulhat ki a „magányos”, egyetlen nagyváros egyik szélsőségként illetve kis- és középvárosok túl domináns központ nélküli hálója a másik szélsőségként, illetve ezek valamilyen keveréke.

A városok további fejlődését a gazdaság fejlődése, az infrastruktúra és a szomszédos városok távolsága és nagysága, fejlettsége határozza meg többek között. A városok a továbbiakban is vonzerőt gyakorolnak a falusi népességre, az életfeltételek minden szörnyüségeik ellenére jobbak voltak a városokban, mint a falun. A közlekedés fejlödésével a város további területekre terjeszkedhetett ki, bár koncentrált maradt a közlekedés drágasága miatt.

\section{2) Szuburbanizáció}

A szuburbanizáció bekövetkeztét két tényező teszi lehetővé. Egyrészt az újfajta gazdasági-termelési szerkezet, a nehézipar relatív súlyvesztése, a könnyüipar és a szolgáltatások (másképp a második és a harmadik szektor) súlyának növekedése, amely nem kívánja meg nagy tömegek koncentrált munkáját. Másrészt a közlekedés fejlődése, elöször a tömeg-, majd a magánközlekedés elérhetővé és általánossá válása lehetővé tette a munkahely és a lakóhely térbeli elválasztását. A lakosság, elsősorban a középrétegek kiáramlanak a város környékére. A lakosság kiáramlását időben késleltetve követi a munkahelyek kiáramlása. A tehetősebb rétegek kiáramlását tovább erősíti a belvárosban megtelepedő irodák által igényelt terület. A belvárosban dolgozók jelentős része a kül- és kertvárosokból jár be dolgozni. Az addigi többlakásos házakban élést a kertvárosokban zömében a családi házakban lakás váltja fel.

\section{3) Dezurbanizáció és városközi decentralizáció}

A dezurbanizációt, azaz a városi és városkörnyéki területek lélekszámának csökkenését, és az addigi falusi területek népességének növekedését elömozdító tényezők, a szuburbanizációhoz hasonlóan, egyrészt a termelési módban, másrészt a 
Kocsis János Balázs : A szuburbanizáció jelenségének főbb elméleti megközelítései a városszociológiai

és más rokon tudományterületek irodalmában. Tér és Társadalom 14. évf. 2000/2-3. 311-321. p.

TÉT XIV. évf. 2000 2-3

A szuburbanizáció jelenségének... 315

közlekedésben bekövetkezett változásokban kereshetők. A gazdaságban a posztfordista átalakulás, a „tudásipar” (kvaterner szektor) megjelenése és tömegessé válása szükségtelenné teszi a munkaerö nagyobb koncentrációját. A közlekedés a városok körül a nagymérvủ gépkocsihasználat folytán ellehetetlenedik, a dugók folyamatossá válnak, s ezáltal a belváros a bejárók számára megközelíthetetlen lesz. Hasonló okokból a gazdasági vállalkozások is a kocsival könnyen és jól elérhetô helyeket keresik, amelyek ráadásul olcsóbbak is, mint a városmaghoz közelebb fekvők. A város szerkezetét a közlekedési káoszt megoldani, csökkenteni kívánó erőfeszitések is mind inkább tönkreteszik: a városmagot behálózó autópályák, többsávos utak, nagyméretü parkolók a belváros vonzerejét jelentősen csökkentik, szerkezetét szétverik.

\section{4) Reurbanizáció}

A reurbanizációt, azaz újravárosodást $L$ v van den Berg (1982) szkeptikusan szemléli, a jövő egyik lehetséges, ámbár nem túl valószinủ fejlődési fázisát látja benne ${ }^{6}$. Akkor tartják valószinủnek, ha aktív várospolitikával a belváros vonzerejét újból visszaállítva, mind a lakók, mind a gazdasági vállalkozások számára vonzóvá válik. Mások, e tekintetben optimistábbak szerint a termelési mód változásai, amelyek a dezurbanizációt is lehetővé tették, a városi életkörülményekben is nagymértékủ javulást hoznak, a népesség bizonyos csoportjait újra a városba:vonzzák. $\mathrm{E}$ kérdés további vizsgálata átvezetne a dzsentrifikáció vizsgálatába, amely túlmuutat e munka keretein.

\section{A historicista megközelítés}

A historicista megközelítés két csoportra osztható. A neomarxisták a termelési módot veszik független változónak, a neoweberiánusok a társadalmi-gazdasági szerveződést. A szuburbanizációs folyamatok megítélése céljából e kettő közötti eltérés az elemzésben nem jelent lényeges eltérést. A historicista megközelítés tagadja az azonos fázisok lineáris egymás utáni felléptét; minden ország, város fejlỏdésének egyediségét hangsúlyozza a nyilvánvaló és természetesen vizsgálandó hasonlóságok, analógiák mellett.

Szelényi (1996) alapján vázolt megközelítés mellett további, főképp marxista megközelítések leírása található Savage-Warde (1993, 40-61) müvében.

\section{2. ÁBRA}

$A z$ urbanizációs folyamat historicista magyarázata

(Historitistic Interpretation of the Urbanisation Process)

Független változó

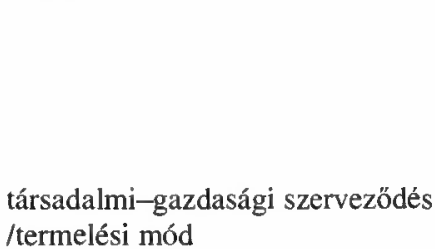

/termelési mód
Közbejövő változó(k)

indusztrializáció

Függő változó

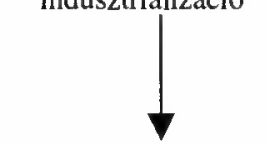

urbanizáció

Forrás: Szelényi 1996. 
Kocsis János Balázs : A szuburbanizáció jelenségének föbb elméleti megközelítései a városszociológiai és más rokon tudományterületek irodalmában. Tér és Társadalom 14. évf. 2000/2-3. 311-321. p.

A két elméleti megközelítés különbsége az elemzési szint tekintetében és a gyakorlatban is jelentös.

A historicista megközelítés szerint általános, lineáris modellt nem lehet fölállítani a városfejlödésben. Az egyes városok esetében a fázisok sorrendje is különbözhet, egyesek elmaradnak, mások csak ott szerepelnek, s ezt az adott társadalom társadalmi-gazdasági szerveződése határozza meg elsősorban. Modelltípusokat és folyamatokat határozhatunk meg, s ezek sem kizárólagosak - egy bizonyos város más-más szempontból (világgazdaságban elfoglalt helye, földrajzi környezete, az egy bizonyos időben jellemző termelési mód, a város felépítése) más-más osztályozás alá kerülhet.

\section{A szuburbanizáció okai}

A szuburbanizációnak, mivel egy időben nagyon elhúzódó folyamat, az idő más és más pontjában eltérỏ okai lehetnek, illetve ezeknek az okoknak egy más összetétele magyarázza jobban az adott időszak tendenciáit. Szükségesnek tartjuk az ún. „népi" magyarázatok megemlítését is, mivel ezek egyrészt gyakran megjelennek a médiában is, másrészt a kiköltözök és gyakran a kutatók is ezt hozzák fel oknak.

Az urbanizációval kapcsolatos (föképp amerikai) elméletek és egy új lehetséges paradigma felvázolását részletesen Gottdiener tárgyalja, egyfajta szintézist teremtve az ökológiai és a neomarxista elméletek között (Gottdiener 1985).

A továbbiak elött szükséges az okok két fajtáját elkülöníteni (Gottdiener 1985): a vonzó tényezöt (pull factor), amellyel a kialakuló vagy már kialakult szuburbia vonzza a népességet, illetve a taszító tényezöt (push factor), amely az addigi belvárosi lakóhelyükről készteti az embereket elköltözésre. A két tényezö nagysága, az egyik vagy másik, akár mindkettő meglétének hiánya nagyban befolyásolja a folyamatot, de Gottdiener szerint megakadályozni nem tudja ${ }^{7}$. Például az amerikai szuburbanizáció kezdeti korszakában „a várost kellemesnek találták, olyan helynek, ahol jó élni"(Gottdiener 1985, 10). A továbbiakban ezen a vonzó és taszító tényezök mibenlétére mutatunk be elméleteket. Az egyes elméleteket nem egymást kizárónak, hanem egymást kiegészitőnek tekintjük, még akkor is, ha a korábbiakban ismertetett ökológiai és historicista ${ }^{8}$ szemléletbeli eltérések elég nagyok.

A közvélekedés szerint, amellyel a szakirodalom jelentős része egyetért, az emberek azért költöznek ki a városból, mert az büdös, piszkos, magas a bủnözés aránya, a gyermekek nevelésére alkalmatlan, teljesen el van szakítva a természettől. A városon kívül tiszta a környezet és a levegő, alig van búnözés (legalábbis nem látható), a gyermekeknek ideális hely a fejlödéshez, a természet is „az ajtó elött hever”. A domborzat szerepe is jelentős, a földrajzi magasság a szociális státusz mutatóeszköze: minél magasabban lakik valaki a Város fölött, annál magasabb helyet foglal el a hierarchiában? . 
Kocsis János Balázs : A szuburbanizáció jelenségének föbb elméleti megközelítései a városszociológiai

és más rokon tudományterületek irodalmában. Tér és Társadalom 14. évf. 2000/2-3. 311-321. p.

TÉT XIV. évf. 2000 — 2-3

A szuburbanizáció jelenségének... 317

\section{A) Az egyensúly-elmélet}

A városszociológiában jelenleg a legelfogadottabb elmélet, legalábbis Gottdiener szerint (Gottdiener 1985, 46) az egyensúly-elmélet (equilibrium theory). Első jelentős kidolgozója Alonso volt 1964-ben, s azóta is sokan bővítették. Mások az elméletet egyensúly-hiány elméletnek (imbalance theory) nevezték inkább, ők a hangsúlyt a változást előidézỏ okokra helyezték ${ }^{10}$. Ezek a modellek egy, minden szükséges információval ellátott, racionálisan döntỏ embert (homo racionalis vagy oeconomicus) feltételeznek. A fentiek kétségbevonhatóságán túl is vannak olyan fejlemények, amelyek e modellek ellen szólnak. Részint a közlekedési költségek aránya a szuburbiai lakás árához képest alacsonyak Nyugat-Európában. Másrészt egyre többen nem járnak be a városba, sem dolgozni, sem bevásárolni, így a napi helyváltoztatásuk akár kisebb is lehet, mint a centrumban lakóké. Harmadrészt a modell a belvárosi telekárak drágaságával magyarázza mindeme kalkulációk megtörténtét. A belvárosi drágaságnak ellentmond azonban a nagyméretü belvárosi gettók, lepusztult, avagy kevésbé vonzó területek (a legismertebb példa Harlem, de a Los Angeles-i South Central is lehetne) gyakori megléte. A szocialista városok hasonlóképp ellenérvet szolgáltathatnak: a belvárosokban a szocializmus alatt a területnek nem volt valós ára, a periférián viszont igen. Másrészt a közlekedési költségek sem olyan elhanyagolhatóak a lakhatás egyéb költségei mellett. Harmadrészt a divatos perifériákon a telek ára meghaladja egy belvárosi lakás árát.

\section{B) Historicista elméletek}

Ezen elméletek egy gazdasági-társadalmi szerkezet kifejeződését látják a szuburbanizációban. Elkülönítik a szuburbanizáció okait és nagymértékủ elterjedését elösegítő tényezőket.

Fishman (1987) a szuburbanizáció feltételének két tényezőt tekint, a központban tömörülő lehetöségeket és ugyanezen központ lakhatásra való alkalmatlanságát, ami fönnállt a XVII. század végi London illetve később más európai és amerikai nagyváros esetében. A szuburbanizáció további feltétele, hogy a lakó- illetve a munkahely egysége már nem fontos a középosztály számára, azt fel tudja adni.

A szuburbanizáció okainak a családi élet középpontba kerülését, azaz a családnak a külvilágtól való szeparálódását, illetve a társadalmi osztályok szegregációját tartja. Az elöbbi eszme a XIX. század folyamán a nyugati világ jelentős térségeiben elterjedt, átalakítva a várost és a társadalmat. Addig az emberek ugyanazon a környéken éltek, viszont a rang és gazdagság megannyi jelével felvértezve különítették el egymástól a társadalmi rétegeket, e jelek gyengülésével a lakóhelyi szegregáció lépett fel jelentös megkülönböztetö tényezővé. Mint ahogy egy kortárs megjegyzi: az alsó osztályok hirtelen büdösek lettek (Fishman 1987, 32).

Savage és Warde (1993) a városban a XVIII. századtól létrejövő elkülönült területek, azaz a gettók, a szuburbiák és a dzsentrifikált (belvárosi) beékelések kialakulása okainak a társadalmi rétegek fokozódó szegregálódását tartja. E szegregációnak 
Kocsis János Balázs : A szuburbanizáció jelenségének föbb elméleti megközelítései a városszociológiai és más rokon tudományterületek irodalmában. Tér és Társadalom 14. évf. 2000/2-3. 311-321. p.

TÉT XIV. évf. 2000 - 2-3

az az oka, hogy a rendelkezésre álló hely szúkös, így a területeknek eltérö értéke van elhelyezkedése, nagysága stb. szerint, ami a városrészek elkülönüléséhez vezet. Az elkülönülés (mind a gazdasági, mind az etnikai) csoportok térbeli elkülönüléséhez vezet. A területek funkcionális elkülönülése vezetett Burgess klasszikus körkörös városképéhez, legbelül a központi üzleti negyeddel (CBD - Central Business District), s legkívül a gazdagok lakóterületeivel. A kidolgozott modellek empirikus vizsgálata arra az eredményre vezetett, hogy ,a társadalmi-gazdasági státusz (például a társadalmi osztály) földrajza nagyjából szektoriális, a családi státuszé nagyjából zónás (a fiatal családok a külső szuburbiákban, a lakásbérlök közelebb a városközponthoz), míg az etnikai státuszé szignifikáns csoportosulást mutatott mind a zónákban, mind a szektorokban". A szerzök szintén nagy hangsúlyt fektetnek a családi élet átalakulásának, a nukleáris család elterjedésének. Mind a szuburbanizáció okaként, mind a dzsentrifikáció okaként e családmodell további átalakulását tartják (Savage-Warde 1993, 76).

A szuburbanizálódást létrehozó fő tényezőnek tekintik a motorizációt, különös tekintettel a gépkocsi elterjedésére. Ez a vélemény abban fejeződik ki legjobban, hogy sokak szerint a gépkocsi megjelenésével az ember a neki való helyen élhet. Azonban, mint Fishman rámutat, ez is egy eszköze volt csak a sokkal általánosabb tendenciának, a klasszikus szuburbia a vasutak mentén alakult ki. Az elérhetőség a szuburbia számára pontosan olyan fontos, mint a nehezen elérhetőség: a gyors és egyszerü elérhetőség azok számára, akik ezt meg tudják fizetni, az elérhetetlenség az alsó osztályok számára (Fishman 1987). A szuburbanizációt lehetővé tevő tényezők közé tartozik még a (tömeg-) kommunikáció elterjedése, amely szintén a fizikai távolságok csökkenése felé hatott, lehetövé téve nagy távolságokban szétszórt emberek gyors, mindennapi kapcsolattartását.

Mindezen tényezők csak bizonyos feltételek megléte mellett vezettek szuburbanizációhoz. Részben föképp az angolszász országokban meglévő antiurbánus hagyomány magyarázza azt, hogy a belvárost hagyták lepusztulni, másrészt spekulációs okok, a modellkövetés. Az angolszász hagyomány irtózik a nagy állami szerepvállalásoktól, amit a belvárosnak a középosztály igényeire való átalakítása igényelt volna, Franciaországban az állam Haussmann-nal az élen szinte teljhatalommal elérte azt, hogy a belváros maradt a középosztály lakóhelye.

Az emberek által követett modellek szerepe jelentős a szuburbanizáció folyamatában is. A manchesteri szuburbanizációt gyakorlatilag egy bizonyos Brooks indította el 1834-ben, akit hamarosan követtek barátai, majd a felső rétegek (Fishman 1987, 81), kialakítva a későbbiekben Burgess által leirt körkörös szerkezetet. A modellátadásnak a szuburbanizáció elkerülésekor is jelentős szerepe volt: a párizsi burzsoázia számára a kívánatos lakóhely nem a vidéki villa, hanem a belvárosi palota volt, mint ahogy a minta sem a vidéki (angol) arisztokrácia, hanem a (párizsi) királyi udvar és arisztokrácia. A modellátadás kapcsán föként Georg Simmelnek „A divat” címü 1911-ben írt munkájának gondolatait használjuk fel (Simmel 1973). Simmel vizsgálatát az is indokolja, hogy munkái jelentősen befolyásolták a Chicagói Iskola elméleteit. 
Kocsis János Balázs : A szuburbanizáció jelenségének föbb elméleti megközelítései a városszociológiai

és más rokon tudományterületek irodalmában. Tér és Társadalom 14. évf. 2000/2-3. 311-321. p.

TÉT XIV. évf. 2000 -2-3

A szuburbanizáció jelenségének...

319

Simmel alapfeltevése szerint „a társadalom egész története felfogható két tényező, a társadalmi csoportunkba való beolvadás és az ebböl történő kiemelkedés harcának..." (Simmel 1973, 474). Kétfajta embertípust különböztet meg, az utánzót, aki az általánosságban akar felolvadni, és a célkitüzőt, akit a hagyományokon kívül a jövő is meghatároz. E két irány küzd az emberben, ez a divat alapja: „A divat egy adott minta utánzása, (...) az egyént arra az útra vezeti, amelyen mindenki jár. (...) De ugyanilyen mértékben tesz eleget a különbség igényének, a differenciálódás tendenciájának, a változásnak és a kiemelkedésnek is" (Simmel 1973, 476).

A téma szempontjából alapvetö, hogy a „divat, mint mondottam, az osztályok elkülönülésének terméke, (...) amelynek kettős funkciója az, hogy bizonyos kört összetartsanak, s egyúttal másoktól elhatárolódjanak. (...) ... a divat is egyfelöl az azonos helyzetben lévőkhöz való csatlakozást, az általa (a divat által) jellemzett kör egységét jelenti, s éppen éppen ezáltal azt is, hogy e csoport elhatárolja magát az alacsonyabb helyzetben lévőktöl" (Simmel 1973, 476-477).

Ha a divatban mintaadó elit külföldi, mint Magyarországon a felső osztályok hiánya miatt a „divat külső eredete valójában különösen javára válik azon körök belső összetartozásának, melyek felkapják, éppen mivel kívülröl származik, a szocializáció azon különleges és jelentős formáját hozza létre, ami egy külső tényezöhöz való közös kapcsolat eredményeként jelenik meg" (Simmel 1973, 480).

Simmelhez hasonlóan érvel Jean Baudrillard is az 1970-ben megjelent La société de consommation (A fogyasztás társadalma) címü müvében, amelynek témánkat érintő mondanivalóját Haumont így foglalja össze: „A fogyasztás társadalmában az egyének, a háztartások és a csoportok már nem csak azért kívánják a javakat és szolgáltatásokat, hogy használják, hanem azért is, mert ezek a presztízs, az elkülönülés, a társadalmi osztály jelei. És ahogy nem lehet elképzelni a különbözö társadalmi pozíciókért folyó vetélkedés és verseny végét, úgy nincsen helye azt képzelni, hogy vége lehet a jelek fogyasztásának és a fogyasztás permanens folytatódásának" (Haumont, évszám nélkül).

Herbert J. Gans (1967) egy New Jersey-i szuburbot vizsgálva a mintakövetésnek jóval kisebb szerepet tulajdonít, a tömegkommunikáció hatását pedig csak mint a már kialakult értékek hangoztatásában, az értékek változását csak némileg lemaradva követi (Gans 1967). A szuburbanizálódás okait részint a nagy alapterületủ családi házat mint ideális lakásformát preferáló amerikai hagyományokban látja, másrészt a városból taszító tényezőkben: a megfelelö és kellöen modern hely hiányában a hagyományos középosztálybeli lakóhelyeken, illetve az újonnan bevándorló rétegek által kifejtett nyomásban. Nem elhanyagolható szerepet játszott a családok további szétválása, a megfelelỏ anyagi körülmények lehetővé tették a fiatalok számára a szülőktöl való elköltözést. Gans szerint a helyi politika csak követte a meglévő igényeket, nem meghatározta azokat.

Mint Gottdiener megállapítja: „nagyjából látható, hogy mi történik, csak nem pontosan tudjuk, miért" (Gottdiener 1985, 16). A szuburbanizáció okainak megértéséhez sok különbözö elméletet kell megvizsgálnunk és alkalmaznunk a konkrét városra. 
Kocsis János Balázs : A szuburbanizáció jelenségének föbb elméleti megközelítései a városszociológiai és más rokon tudományterületek irodalmában. Tér és Társadalom 14. évf. 2000/2-3. 311-321. p.

\section{Jegyzetek}

${ }^{1}$ Más szempontból való felosztásra lásd például Timár J. (1999).

${ }^{2}$ Arra vonatkozóan, hogy maga a modell milyen, ez a típusú megközelítés nem ad elméleti feltevéseket, csak az azonosságát hangsúlyozza.

${ }^{3}$ Az újabb ökológiai modellek az indusztrializáció helyett a termelési mód változásaival, azaz a poszfordista termelési módba való átmenettel magyarázzák a városfejlödés általános szakaszait, így megörizve az indusztrializáció központi szerepét (Enyedi 1996).

${ }^{4}$ P. Hall modelljét idézi Savage-Warde (1993, 37), múvét európai városokról írta 1980-ban és 1988-ban.

${ }^{5}$ Ez az állapot volt a Chicagói Iskola tanulmányainak középpontjában (Savage-Warde 1993).

${ }^{6}$ Ök az urbanizációs változások valószinübb kifejletét a dezurbanizáció kiteljesedésében látják inkább.

${ }^{7}$ Szerinte a szuburbanizáció nem a város hanyatlásának jele, hanem egy általános dekoncentrálódásé.

${ }^{8}$ Ezt a szemléletet az amerikai szakirodalom neomarxistának hívja.

${ }^{9}$ Leendő szociológusok, azaz felvételire készülök körében általános nézet volt, azzal együtt, hogy a világon ez máshol is így van. Ezzel szemben Rio de Janeiroban a legszegényebbeknek van a legjobb kilátásuk a városra.

${ }^{10} \mathrm{Az}$ egyensúly-hiány elméletek inkább a térben nagyobb léptékủ változások magyarázatát tekintették céljuknak.

\section{Irodalom}

Berg, L. van den, et al. (1982) A Study of Growth and Decline. Urban Europe. New York, Pergamon Press. 25-48.; 77-104. o.

Enyedi Gy. (1996) Regionális folyamatok Magyarországon. Budapest, Hilscher Rezsö Szociálpolitikai Egyesület.

Fishman, R. (1987) Bourgeois Utopias: The Rise and Fall of Suburbia. New York, Basic Books.

Frieden, B.J.-Sagalyn, L.B (1997) Downtown. Cambridge, Massachusetts.

Gans, H.J. (1967) The Levittowners. New York, Columbia Univ Press.

Garreau, J. (1991) Edge City. New York, Anchor.

Gottdiener, M. (1985) The Social Production of the Urban Space. Austin, Univ of Texas.

Jackson, K.T. (1985) Crabgrass Frontier. New York-Oxford.

Haumont, A. (évszám nélkül) La mobilité intra-urbaine. Université Paris 7.

Savage, M.-Warde, A. (1993) Urban Sociology, Capitalism and Modernity. New York, Continuum Pub Group.

Simmel G. (1973) A divat. Válogatott társadalomelméleti tanulmányok. Budapest, Gondolat. 473-507. o.

Szelényi, I. (1996) Cities under Socialism - and After. Cities after Socialism. - Andrusz, G.-Harloe, M.Szelényi, 1. (eds.), Oxford, Blackwell. 286-317. o.

Timár J. (1999) Elméleti kérdések a szuburbanizációról. - Földrajzi Értesitö. 1-2. 7-31. o.

Tosits I. (szerk.) (1998) Szuburbanizációs tendenciák és településfejlesztési stratégiák Budapesten és agglomerációjában. Kézirat. Budapest, Városkutatás Kft.

\section{PRINCIPAL THEORETICAL APPROACHES OF THE PHENOMENON OF SUBURBANISATION IN THE LITERATURE OF URBAN SOCIOLOGY AND OTHER RELATED SCIENCES}

\section{JÁNOS BALÁZS KOCSIS}

The suburbanisation phenomena has a strong impact on today's urban processes in Hungary, especially in the case of Budapest. The disciplines studying this theme have put forward several theories to describe these phenomena from their special point of view. 
Kocsis János Balázs : A szuburbanizáció jelenségének föbb elméleti megközelítései a városszociológiai

és más rokon tudományterületek irodalmában. Tér és Társadalom 14. évf. 2000/2-3. 311-321. p.

TÉT XIV. évf. 2000 - 2-3

A szuburbanizáció jelenségének... 321

Amongst the architectural and the geographical approaches the paper deals mainly with the two theoretical traditions in urban sociology, according to I. Szelenyi and places the theories found in the literature in this framework. The ecological or evolutionary tradition sets up a universal straight line in the urbanisation process where each town takes up a position appropriate to the ecological status as the ecology progresses take a step forward. The steps have the same order in every society, the social-ecological structure only alters the appearance of the actual step. The historical tradition reverses the relation, according to its neo-marxist branch the mode of production is the basic factor in the actual urban formation, the neo-weberian branch considers the social-ecological organisation as the independent variable, whilst the state of the ecology is the intervening variable in both branches. The difference between these two traditions sketches two strongly different urbanisation processes and presence of cities. The paper describes some of these theories in the frame of the theories. 